\title{
Challenges and Opportunities in the Use of Marketing Tools and the Promotion of Non Wood Forest Products-Based Small and Medium Enterprises in the South East Europe
}

\author{
Makedonka Stojanovska ${ }^{1 \rrbracket}$, Dragan Nonić ${ }^{2}$, Jana Baumgartner ${ }^{1}$, \\ Jelena Nedeljković ${ }^{2}$, Vladimir Stojanovski ${ }^{3}$, Vaska Nedanovska ${ }^{1,}$ \\ Stjepan Posavec ${ }^{4}$
}

1 Ss. Cyril and Methodius University in Skopje, Faculty of Forestry, Aleksandar Makedonski bb, MK-1000 Skopje, Macedonia, the former Yugoslav Republic of

2 University of Belgrade, Faculty of Forestry, Kneza Višeslava 1, RS-11030 Belgrade, Serbia

${ }^{3} \mathrm{PhD}$ student, BOKU - University of Natural Resources and Life Sciences, Gregor-Mendel-Straße 33, AT-1180 Vienna, Austria

${ }^{4}$ University of Zagreb, Faculty of Forestry, Svetošimunska 25, HR-10000 Zagreb, Croatia

$\triangle$ Corresponding author: e-mail: makedonka@sf.ukim.edu.mk

Citation:

STOJANOVSKA M, NONIĆ D, BAUMGARTNER J, NEDELKOVIĆ J, STOJANOVSKI V, NEDANOVSKA V, POSAVEC S 2015 Challenges and Opportunities in the Use of Marketing Tools and the Promotion of Non Wood Forest Products-Based Small and Medium Enterprises in the South East Europe. South-east Eur for 6 (1): 97-106. DOI: http://dx.doi.org/10.15177/seefor.15-02

\section{Abstract}

Background and Purpose: The South-East Europe (SEE) region is facing a new market economy era where establishing new businesses is more than needed in all sectors. The forest sector, faced with new market emerging opportunities, is affected by the constant increase of a number of forest related enterprises. This paper describes the challenges and opportunities related to the use of marketing tools for improving business of the small and medium enterprises (SMEs) dealing with non-wood forest products (NWFPs) in SEE region. The research on this subject in the SEE region is scarce despite the rich biodiversity as a solid base for establishing eco-businesses.

Materials and Methods: The method used in this paper is quantitative, based on survey data collected from enterprises in the NWFPs sector followed by statistical data analyses using Statistical Package for Social Sciences (SPSS). The survey was conducted during 2011 and 2012 in four SEE countries: Croatia, Bosnia and Herzegovina, Serbia and Macedonia.

Results: The results showed that developed channels of distribution, branding and advertising of NWFPs are recognized in all countries as important and very important, but these marketing tools are used only few times per year. The majority of respondents pointed out advertising as the most frequently used and 
as the most successful tool. Interviewees' future investments are to be focused on improving equipment for drying, packing, refrigerating and transport. Several entrepreneurs from Macedonia pointed out that they would invest in increasing the number of buying points and herb plantations while almost all Croatian entrepreneurs will invest in advertising, branding and promotion. Majority of respondents from Serbia are also of the opinion that financial resources should be invested in new equipment. The reasons for these investments can be summarized in reducing costs and increasing profit or in faster turnover.

Conclusions: The use of marketing tools is important because they have positive influence on sale, improve communication and cooperation between enterprises and with consumers, build reliable buyers and increase the number of consumers, which leads to higher profit and creates new opportunities for NWFPs based enterprises. Intensive use of promotion tools should be seen as an opportunity for these enterprises in the SEE region to overcome current challenges and improve their business. The main reason for this situation, as it was stated in the interviews, is the fact that most of the enterprises do not have a final product. Another reason is lack of funds, because of which the question: "If you have financial sources where you should invest?" was answered with promotion, branding and other marketing tools.

Keywords: non-wood forest products, small and medium enterprises, promotion, SEE region

\section{INTRODUCTION}

Small and medium enterprises (SMEs) play a key role in the national, regional and global economy, and provide outsourcing products and services [1]. Products such as mushrooms, herbs, wild berries and other forest fruits (commonly known as non-wood forest products-NWFPs ${ }^{1}$ ) are an important aspect in the sustainable management of forests. Thus, in order to increase the contribution of this sector to the economic and social development, it is necessary to support the establishment and development of SMEs that base their business not only on wood, but also on NWFPs [2].

There are several factors that can influence the competitive advantage of SMEs. The literature emphasises "the importance of marketing, strategic positioning, and entrepreneurship as key factors in business survival and growth. The ability to identify and operate in a particular market niche enables the firm to exploit a range of specializations and offers protection from larger competitors" [4]. However, marketing in SMEs differs from these activities in large enterprises. Marketing in SMEs is characterised as "haphazard, informal, loose, unstructured, spontaneous, reactive, built on as well as conforming to industry norms" [5].

This means that significant attention should be given to activities such as production, marketing and promotion. Promotion, as a business activity, is a significant tool for future development of every business, closely connected to increasing employment, poverty elevation, and income of the company [6-8]. Promotion is of great importance and can be a major advantage, especially if SMEs have limited financial resources, but good competences in promotion techniques. Powerful tools to reduce the problems of marketing access for SMEs are, in some cases, e-business and e-marketing.

Promotion is a part of marketing referring to the advertising and selling. It is a mechanism of communication: exchange of information between sellers and consumers [9]. The purpose of promotion is to get people to understand what one product is, what they can use it for, and what is the desire for it. A product or service means nothing unless the benefit of such a service can be communicated clearly to the target market [10]. To be effective, promotional efforts should contain a clear message targeted at a specific audience reached via an appropriate

\footnotetext{
${ }^{1}$ NWFPs are "goods of biological origin other than wood, derived from forests, other wooded land and trees outside forests" [3]. In this paper, as NWFPs are considered: mushrooms, medicinal and aromatic plants, wild berries and other forest fruits.
} 
channel. Promotion may involve advertising, public relations, personal selling, and sales promotions [8-10].

Marketing definitions, such as marketing as "a social and managerial process by which individuals and groups obtain what they need through creating and exchanging products and values with others" [10] may not necessarily apply to the small firm context due to its unique characteristics. Existing literature has emphasized the need to develop and refine existing marketing models, which can be used to profile the marketing practices in small firms [11].

SMEs are known to be the heart of strong economies, as well as being the backbone of development in rural areas and small towns [12]. Small business marketing consists of business activities relating to: identifying a target market, analysing its potential, and delivering what it takes to satisfy the market [13]. Small firms typically have different requirements with respect to marketing, with their inherent characteristics impacting upon the willingness/ ability of the owner/manager to use conventional and/or contemporary marketing tools [14].

Marketing activities such as advertising, public relationships (PR) or branding are not considered to be relevant for successful working of the SMEs, although personal word of mouth communication [15], the characteristics of owners/managers such as skills, abilities, resources [16], and on-going dialog with existing and new customers [15] seem to be a more acceptable practice. Other marketing characteristics of the SMEs are the limited specialist expertise (owners/managers tend to be generalists rather than specialists) and limited impact in the marketplace [17]. Building personal relationships is vital to the company's success and considerable time and effort are invested in maintaining good relations with regular clients [17].

The research on this subject, and especially comparisons between different countries in the SEE region are scarce. In order to ensure the economic benefits of these products, and their sustainable use, special attention should be paid to marketing of NWFPs [18, 19]. Thus, the main goal of this research is to determine the challenges and opportunities of existing SMEs in the SEE region dealing with NWFPs related to promotion activities in order to improve their current business. The main research question is: "What are the main promotion activities of NWFPs based small and medium enterprises in the SEE region?".

\section{CONCEPTUAL FRAMEWORK}

Businesses face the challenge with macro trends such as globalization, hyper-competition and the Internet [20] in finding ways to maintain prices and profitability [20]. For example the concept of total product [21] offer three components that can help small and medium sized firms to differentiate their product from those of competitors: quality, reputation and service [21].

Developing detailed framework for the marketing process, including an entire set of specific activities to be performed to meet management's strategic goals and objectives [22], is a part of facing marketing challenges for the SMEs. The main answers seem to be better segmentation, stronger branding, and superior customer relationship management [20].

The unique characteristics of SMEs do not perfectly fit into the traditional marketing theory $[15,17]$ because the SME owners/managers behave and think differently from conventional marketing decision-making practices in large companies [17].

Most SMEs will have a product or a service, which they will offer at a price and which they will promote through some kind of medium that reaches their market place [10] (Figure 1). It can be easily determined that SMEs marketing can be described under the frameworks of the 'four Ps'- '4Ps' [23].

For an SME practitioner to accept a concept such as the '4P's' it must have relevance, therefore, if a simple '4Ps' description is not relevant to an entrepreneur it will not be used [23] 


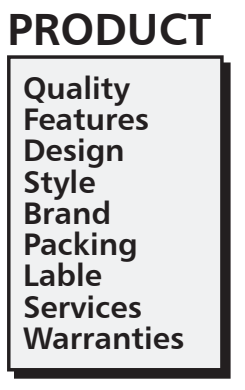

PRICE

Pricing strategy
Discounts
Allowanes
Payment period
Credit items
Handling charges

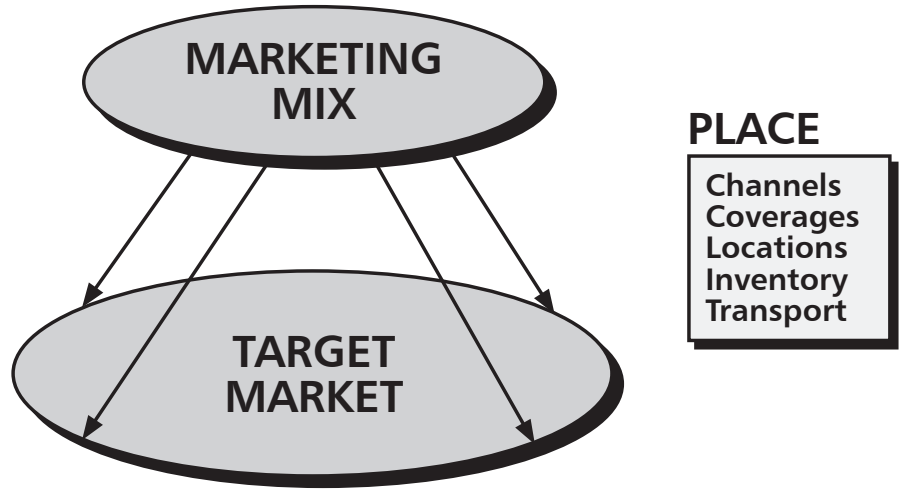

PLACE

Channels

Transport

FIGURE 1. 4Ps in marketing (adapted from Kotler et al. [10])

However, marketing activities in SMEs will always by pragmatic, practical and relevant to the individual SME [22]. Resnick and Cheng [15] in their 4Ps model for SMEs marketing conclude that small businesses have personal relations with their customers, that they execute business in hand instead of planning, that services and goods are provided according to customers' demands and that they build longtime customer relationships.

\section{MATERIALS AND METHODS}

The research in this paper is descriptive, because it describes and explains the state of the art of marketing tools usage in SMEs business dealing with NWFPs in the SEE region. Four countries, Bosnia and Herzegovina (B\&H), Croatia, Macedonia and Serbia, participated in this research. These countries were selected because of their potential for NWFPs resources and SME sector based on these products [24].

Using door-to-door survey technique, primary data were collected from 30 companies from
B\&H, 27 from Croatia, 36 from Macedonia and 91 from Serbia. The survey was part of the "Forest Policy and Economics Education and Research" (FOPER II) project and Collaborative Regional Research Teams (CRRTs) topic "Entrepreneurship, markets and marketing of non-timber forest products in SEE region". The necessary data were collected starting from August 2011 until March 2012. Due to the lack of repository system with a list of companies in the NWFPs based sector in the researched countries, the sample size was determined according to the list of registered companies gathered from governmental institutions and from companies willing to participate in this research. Therefore the sample size was not the same for each participating country.

The survey questionnaire consisted of 51 questions, grouped into six topics: 1) sociodemographic characteristics of respondents, 2) basic information about the enterprise, 3) purchasing of NWFPs, 4) processing of NWFPs, 5) selling and trade in NWFPs, 6) business analysis. For this paper seven questions related to promotion activities of small and medium 
enterprises were further analysed and presented more comprehensively. The questionnaire included closed and open-ended questions.

The collected data were quantitatively analysed with Statistical Package for Social Sciences (SPSS) version 18, summarized by frequency distribution, selected measures of location and dispersion (mean and standard deviation) and presented in this paper.

\section{RESULTS}

More than $70 \%$ of the respondents in all four countries find the use of marketing tools such as developed channels of distribution, familiar product (brand), advertising etc., in SME development as an important and very important segment (Figure 2).

According to $86 \%$ of the respondents in $\mathrm{B} \& \mathrm{H}$, marketing activities of developed channels of distribution are important and very important in this sector, followed by advertising with $83 \%$ and familiar product/name (brand) with $79 \%$ of respondents. They also stated that visiting and participating in fairs is very important.

On the contrary, in Croatia most of the respondents $(74 \%)$ are of opinion that having familiar product/name (brand) is an important and very important marketing practise in NWFPs sector, followed by developing channels of distribution (70\%) and advertising (63\%).

Results related to the importance of marketing tools in Macedonia and Serbia are similar. The highest percentage of respondents from both countries $(86 \%$ in Macedonia and $69 \%$ in Serbia) believe that the developed channels of distribution are important and very important as a marketing activity in this sector, followed by familiar product/name (brand) (71\% in Macedonia and $60 \%$ in Serbia) and advertising (55\% in Macedonia and $30 \%$ in Serbia).

Although most of the respondents in all four countries consider these types of marketing activities (public relations, advertising and branding) to be important and very important,

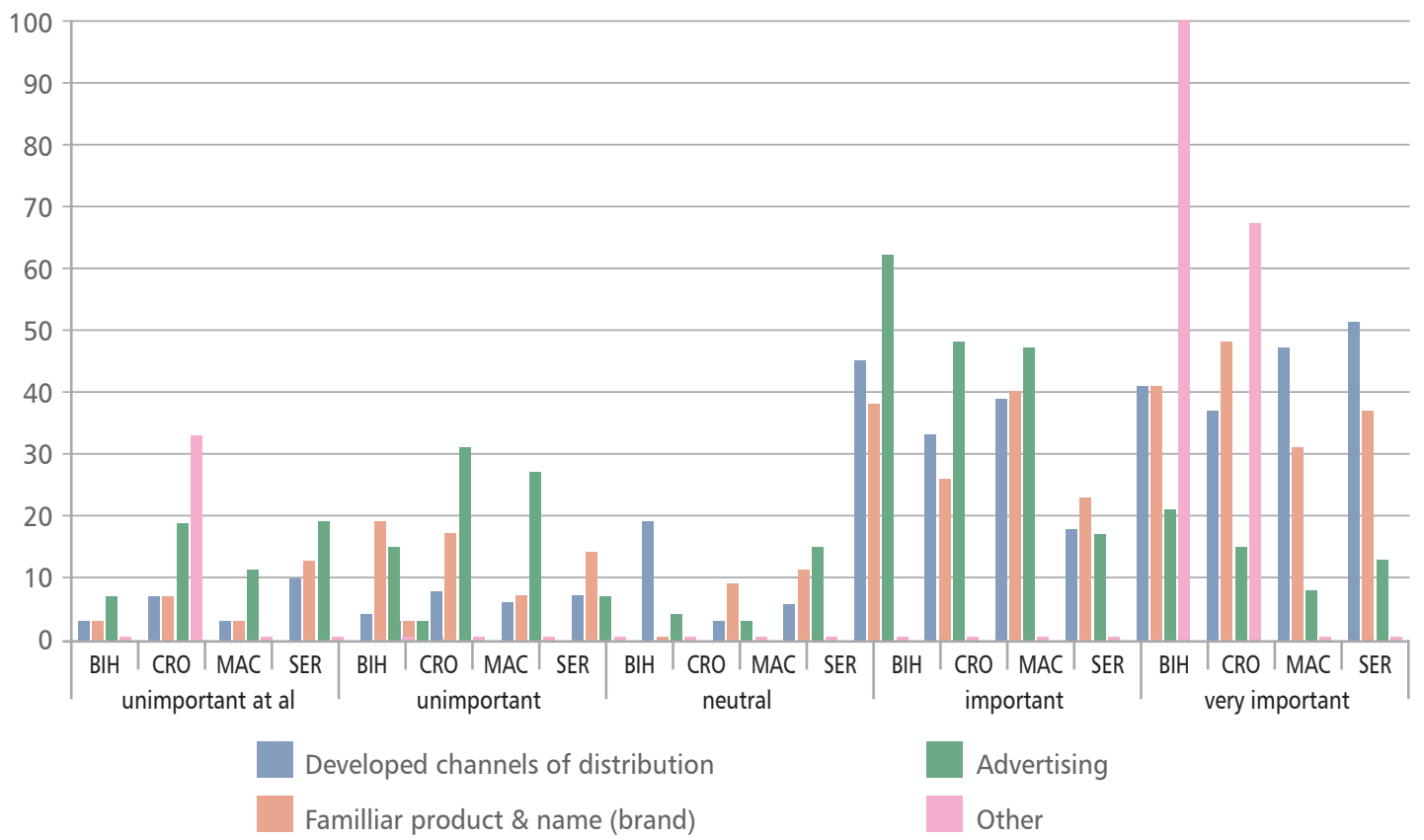

FIGURE 2. The importance of marketing tools in \% by country (sample size: 30 companies in $B \& H ; 71$ companies in Croatia; 36 companies in Macedonia; 91 in Serbia) 
they do not use them in their daily businesses, or they use them only once a year or few times per year (Figure 3).

The results have shown general non-use of marketing tools in observed region, with some differences in observed countries. The most obvious are the results from Macedonia where the highest percentage of respondents answered that they had never used marketing tools $(69.4 \%$ PR; $66.7 \%$ advertising; $88.9 \%$ branding). The situation regarding branding is opposite in B\&H (31\%) and Croatia (25.9\%). However, in Croatia most of the respondents stated that they use PR and advertising "few times per year". Most of the respondents $(57 \%)$ in Serbia stated that they currently use "other" marketing tools, such as international and local fairs, social media, etc. Around $1 / 4$ of them $(24 \%)$ stated that they currently use PR, $28 \%$ advertising and $19 \%$ branding.

Many companies in all four countries have websites and email addresses (Figure 4). It

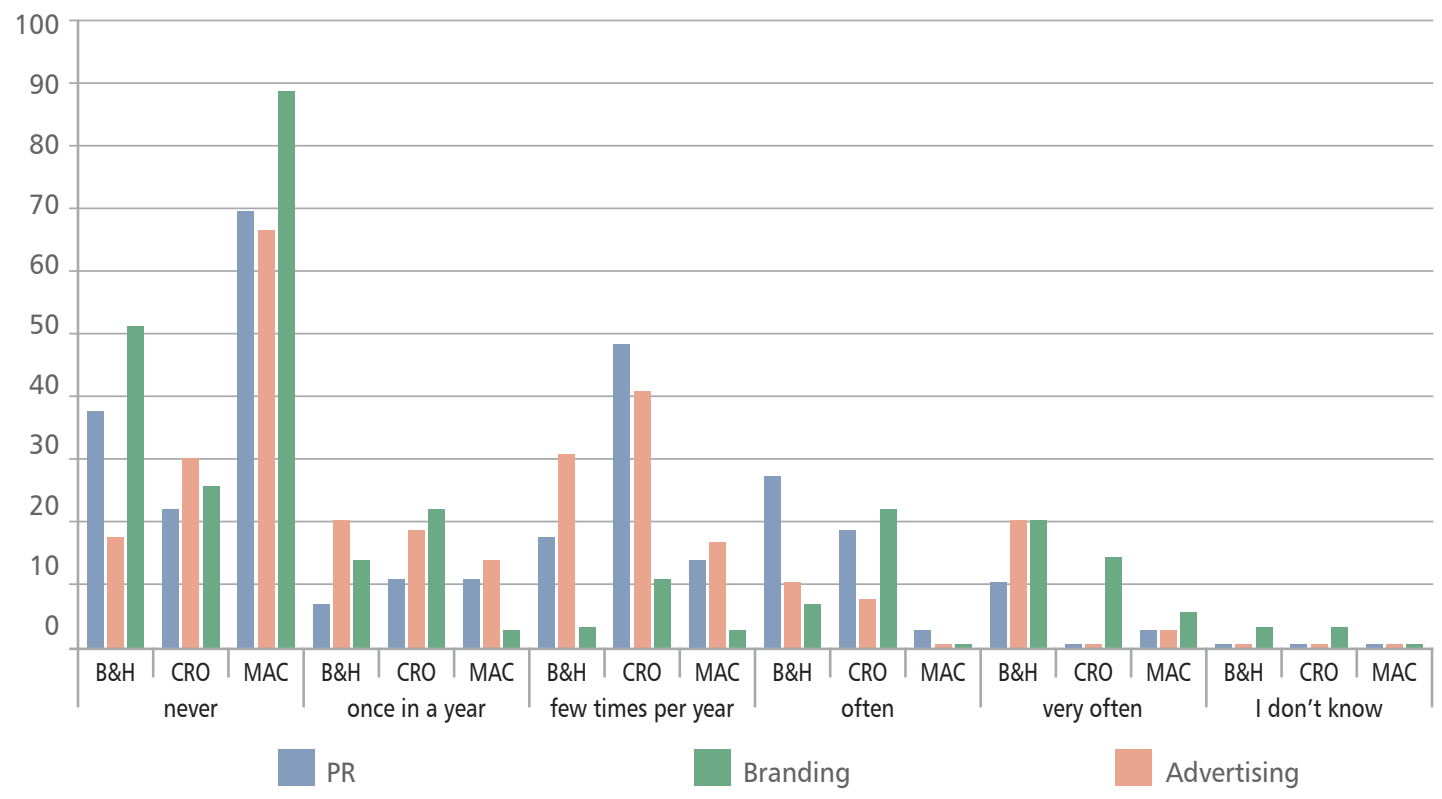

FIGURE 3. The use of marketing tools in \% by country (sample size: 30 companies in B\&H; 71 companies in Croatia; 36 companies in Macedonia). Note: Because of the minor differences in questionnaires used in analyzed countries, data for Serbia are not shown in the figure, but only explained in the text.

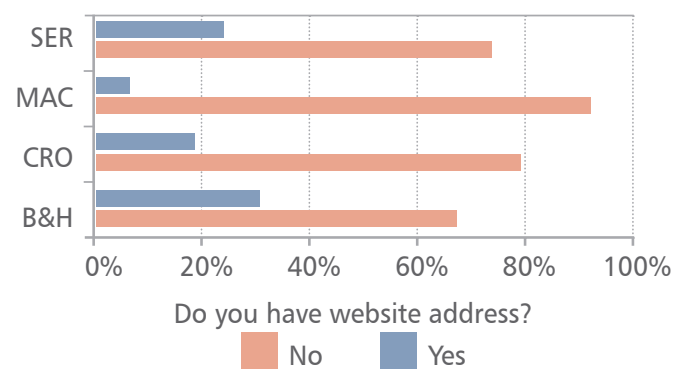

FIGURE 4. The use of websites and email addresses (sample size: 30 companies in B\&H; 71 companies in Croatia; 36 companies in Macedonia; 91 in Serbia) is most visible in Macedonia where $94 \%$ of the respondents have positively answered the question, while more than $60 \%$ of the respondents in $\mathrm{B} \& \mathrm{H}$ stated that they have websites and e-mail addresses.

Advertising through different type of media (broadcast, newspapers, Internet), branding and fairs are the most successful marketing tools in B\&H, Croatia and Macedonia. Respondents from Serbia stated that advertising, branding, and fairs are the most successful marketing tools. An 
interviewee from Macedonia explained that "the marketing tools are very useful for my business, I am aware, but my financial resources allow me to go once per year to agriculture fairs where I present my products. In the future I will start using other tools in order to improve my business". On the other hand, "family brand or branding" was pointed out as a core element in marketing in Croatia, not excluding others as useful marketing tools.

Also, according to the statements of the interviewees from all countries, a conclusion can be drawn that "marketing tools are mostly used to successfully promote companies, products and the quality of the products. At the same time, marketing tools lead to better sale, communication and cooperation between companies and with consumers at the same time, attract reliable buyers and increase the number of consumers". However, the appliance of these marketing tools is restrained due to a lack of financial resources and a final product.

During the survey the interviewees were asked in the case they had financial resources, where they would invest and why in that concrete activity. Most of them stated that they would invest in equipment, in promotion (branding, advertising), in the improvement of quality, in the cultivation and the plantation of NWFPs, in the increase of the number of purchase points and in business expansion.

Reason for investing in this segment is to secure their businesses on a long-term basis. Higher demand means higher profit, satisfying the market needs, the possibility to sell the products at higher price, etc. It is important to highlight that interviewees from Croatia and Macedonia placed promotion on the top of the list because their opinion is that it will enable more people to see their products, which means higher sale and higher profit. It is an open opportunity for expanding production and for a faster turnover. In Serbia and B\&H the respondents stated that their priority was investment in improving the technology and buying new equipment, while in B\&H marketing was not a priority at all.

\section{DISCUSSION AND CONCLUSIONS}

The respondents from the analysed countries have a positive opinion on the importance of developed channels of distribution, branding and advertising. In other words, they point out developed channels of distribution and advertising as the most important marketing tool compared to other marketing tools. Still, their business contacts rely on their previous acquaintances, friendships, relatives as it was stated by one interviewee in Macedonia. Building personal networks is vital to the company's success and they invest considerable time and effort in maintaining good relations with regular clients [17]. Attracting more customers, and thereby increasing business turnaround, is the reason why advertising is important to businesses leading to the increased awareness about the potential of NWFPs [25].

Public Relations, advertising and branding as marketing tools are not often used in daily businesses in NWFPs sector. They are used only once a year or few times per year. According to the results of this research, the uses of such marketing tools for promotion of companies are very rare in the sector of NWFPs in the $\mathrm{SEE}$ region. The most common reason is the lack of the final product along with lacking efficient and effective selling, as it was pointed out by an interviewer from Serbia. The overall quantities of NWFPs are exported either raw or semi raw, but in this state they are not ready for direct distribution to end users/consumers [25].

Even though marketing tools are very rarely used by companies in NWFPs sector in the SEE region $[6,25]$, it can be concluded that in all four countries different marketing tools are often and very often used. According to respondents from $B \& H$, public relation is a tool used often and very and often, while Croatian SMEs often use branding. In Macedonia, equal percentage of often and very often used are PR, while branding and advertising is often and very often used marketing tool in Serbia. 
Due to oversight during the design of this question, as demonstrated by the research itself, the research team noted that confirmative responses referred to existence of an e-mail address, but the answer was ambiguous on the existence of a website. Therefore several confirmative answers referred only to having an e-mail address. Research conducted abroad shows that e-marketing can be useful for the improvement of SMEs' activities related to promotion [7].

As a conclusion and as the data shows, the most successful marketing tools for NWFPs sector in B\&H, Croatia, Serbia and Macedonia are advertising, branding of the products, media, internet and fairs in circumstances when there would be a final product in this sector.

The reasons can be in the fact that enterprises focus on promoting its products and the product's quality. All this leads to achievement of a higher profit, as well as a more economical and efficient manner of working.

The respondents from all countries found that the advanced stage of processing, retail, branded products, a better promotion of companies, the informing of the public and appropriate equipment for the companies are the tools for development of SMEs in NWFPs sector in the SEE region. Additionally, the regulation of the issue of permissions, subsidies, grants, greater use of Instrument for Pre-Accession Assistance funds and soft loans are legislative and supportive measures that would enhance the development of the sector.

According to the respondents, the marketing activities such as advertising, PR and branding were not considered to contribute to SME business at this stage of development due to the fact that the quantities of raw material they collect are not sufficient or they will increase their expenses and decrease their profit. However, several enterprise owners stressed that their personal influence, as well as dialogue and communication with the buyers (the existing and the new ones) could be defined as self-marketing. This perception could be used as a branding tool contributing to a successful business and increased profit. In addition, one owner of a company that purchases and exports NWFPs from Macedonia states that they have "quality raw materials, think of NWFPs, but without a final product and brand name we cannot make anything more. In this way, we will only export semi-final NWFPs, and others who have purchased and have the final costumers will collect the profits and successes". Intensive use of promotion tools should be seen as an opportunity for NWFPs based enterprises in the SEE region to overcome current challenges and improve their business.

The use of conventional marketing tools, particularly those used by large companies (for example branding or the use of PR) in the SEE countries is still challenging, especially for the small and medium enterprises in the nonwood forest products sector, mostly perceived as expensive and non-profit oriented. The research presented the use of marketing tools as very context dependent and not well developed in the daily businesses of small and medium enterprises. However, promoting the establishment of NWFPs SMEs in the developing SEE region by use of marketing tools can bee seen as an opportunity for sustainable use of natural resources, for the improvements of national economies and for eradicating poverty in rural areas.

\section{Acknowledgments}

This study was conducted within the FOPER II CRRT project "Entrepreneurship, markets and marketing of non-timber forest products in SEE region" funded by the Finnish Ministry for Foreign Affairs and project "Research on climate changes and its impact on the environment - monitoring of impacts, adaptation and mitigation" (no. 43007), subproject "Socio-economic development, mitigation and adaptation to climate changes" (no. 43007/16-III), funded by the Ministry of Education, Science and Technological development of the Republic of Serbia. 


\section{REFERENCES}

1. AIDIS R 2005 Institutional barriers to small- and medium-sized enterprise operations in transition countries. Small Bus Econ 25 (4): 305-318. DOI: http://dx.doi.org/10.1007/s11187-003-6463-7

2. NONIĆ D, AVDIBEGOVIĆ M, NEDELKOVIĆ J, RANKOVIĆ N, MARINESCU V, IORAS F 2014 Typology of Non-Wood Forest Products Based Enterprises in Serbia. Not Bot Horti Agrobo 42 (2): 583-587. DOI: http://dx.doi.org/10.1583/nbha4229725

3. FAO 1999 Towards a harmonized definition of nonwood forest product, Unasylva, Issue 198 (50), FAO, Rome, Italy. URL: http://www.fao.org/docrep/ x2450e/x2450e0d.htm (21 September 2014)

4. WALSH M, LIPINSKI J 2009 The role of the marketing function in small and medium sized enterprises. Journal of Small Business and Enterprise Development 16 (4): 569-585. DOI: http://dx.doi.org/10.1108/14626000911000929

5. REIJONEN H 2010 Do all SMEs practice same kind of marketing? Journal of Small Business and Enterprise Development 17 (2): 279-293. DOI: http://dx.doi.org/10.1108/14626001011041274

6. NEDEUKOVIĆ J, KEČA $\amalg 2010$ Analysis of marketing mix elements of non-wood forest products in Central Serbia (in Serbian with English summary). Bulletin of the Faculty of Forestry 102: 83-100. DOI: http://dx.doi.org/10.2298/GSF1002083N

7. PETTENELLA D, SECCO L, MASO D 2007 NWFP\&S Marketing: Lessons Learned and New Development Paths from Case Studies in Some European Countries. Small-scale Forestry 6 (4): 373-390. DOI: http://dx.doi.org/10.1007/s11842-007-9032-0

8. STOJANOVSKA M, NEDANOVSKA $V$, STOJANOVSKI V, NEDELKOVIĆ J, NONIĆ D 2012 The Basic Characteristics of NTFPs-based Enterprises' Business in Macedonia and Serbia. In: Rakonjac Lj. (ed) Forests in Future - Sustainable Use, Risks and Challenges, CD ROM Proceedings from International Scientific Conference, Serbia, Belgrade, 4-5 October 2012. Institute of Forestry, Belgrade, Serbia, pp 757-765

9. MILISAVLEVIĆ M, MARIČIĆ B, GLIGORIEVIĆ M 2009 The basis of marketing. Publishing Center of Faculty of Economics, Belgrade, Serbia, $725 \mathrm{p}$

10. KOTLER P, ARMSTRONG G, WONG V, SAUNDERS J 2008 Principles of marketing (5th European ed.). Prentice Hall, London, England, 1056 p
11. MORIARTY J, JONES R, ROWLEY J, KUPIECTEAHAN B 2008 Marketing in small hotels: a qualitative study. Marketing intelligence \& Planning 26 (3): 293-315. DOl: http://dx.doi. org/10.1108/02634500810871348

12. GETZ D, CARLSON J 2005 Family business in tourism: state of the art. Ann Tourism Res 32 (1): 237-258. DOI: http://dx.doi.org/10.1016/j. annals.2004.07.006

13. LONGENECKER JG, MOORE CW, PETTY JW 2003 Small business management: An Entrepreneurial emphasis ( $12^{\text {th }}$ ed.). Thomson, Ohio, USA.

14. MCCARTAN-QUINN D, CARSON D 2003 Issues which impact upon marketing in the small firm. Small Bus Econ 21 (2): 201-213. DOI: http://dx. doi. org/10.1023/A:1025070107609

15. RESNICK S, CHENG R 2011 Marketing in SMEs: a proposed '4Ps' model. In: Proceedings of the Academy of Marketing Conference, University of Liverpool Management School, Liverpool, England 5-7 July 2011. University of Liverpool Management School, Liverpool, England. URL: https://marketing. conference-services. net/resources/327/2342/pdf/ AM2011 0097.pdf (21 September 2014)

16. O'DWYER M, GILMORE A, CARSON D 2011 Strategic alliances as an element of innovative marketing in SMEs. Journal of Strategic Marketing 19 (1): 91-104. DOI: http://dx.doi.org/10.1080/096 $\underline{5254 X .2010 .537765}$

17. GILMORE A, CARSON D, GRANT K 2001 SME marketing in practice. Marketing Intelligence \& Planning 19 (1): 6-11. DOI: http://dx.doi. org/10.1108/02634500110363583

18. GREENE S, HAMMETT AL, KANT S 2000 Non-Timber Forest Products Marketing Systems and Market Players in Southwest Virginia: Crafts, Medicinal and Herbal and Specialty Wood Products. Journal of Sustainable Forestry 11 (3): 19-39. DOI: http:// dx.doi.org/10.1300/J091v11n03 02

19. PETTENELLA D, KLÖHN S 2007 Mediterranean mushrooms: how to market them. In: Berrahmouni 7, Escuté X, Regato P, Stein C. (eds) Beyond Cork a wealth of resources for People \& Nature, WWF Mediterranean \& IPADE, Madrid, Spain, pp 52-68

20. KOTLER $P 2003$ Marketing insights from $A$ to $Z$ : 80 concepts every manager needs to know. John Wiley \& Sons, Hoboken, New Jersey, USA, 206 p 
21. SMITH R, CESA E, RAPPOLD P 2008 A Marketing Guide for Small and Medium Sized Primary Forest Products Processors. United States Department of Agriculture, Forest Service, Newtown Square, Pennsylvania, USA, $85 \mathrm{p}$

22. HOWE J, BRATKOVICH S 2005 A planning guide for small and medium size wood products companies. United States Department of Agriculture, Forest Service, Newtown Square, Pennsylvania, USA, $91 \mathrm{p}$

23. CARSON D 1999 Marketing for Small-to-Medium Enterprises. In: Baker MJ (ed) The Marketing Book $\left(4^{\text {th }}\right.$ ed), Butterworth-Heinemann, Oxford, England, pp 621-38
24. NEDELKKOVIĆJ, LOVRIĆM, NONIĆD, STOJANOVSKA M, NEDANOVSKA V, LOVRIĆ N, STOJANOVSKI V 2013 Influence of policy instruments on non-wood forest products commercialization in Croatia, Macedonia and Serbia (in Croatian with English summary). Sumar list 137 (9-10): 473-486

25. NEDANOVSKA V 2012 Market potential for non-timber forest products in the Republic of Macedonia. MSc thesis, International Master Program in Forest Policy and Economics, University of Belgrade, Faculty of Forestry, Belgrade, Serbia, $98 p$

(C) 2015 by the Croatian Forest Research Institute. This is an Open Access paper distributed under the terms of the Creative Commons Attribution License (http://creativecommons.org/licenses/by/4.0). 